\title{
Useful interactive teaching tool for learning: Clickers in higher education $^{1}$
}

\section{María-del-Mar Camacho-Miñano ${ }^{2}$ \\ Cristina del Campo}

\author{
School of Business Administration and Economics. \\ Complutense University of Madrid. \\ Madrid (Spain) \\ marcamacho@ccee.ucm.es,campocc@ccee.ucm.es
}

\begin{abstract}
The social changes that appeared nowadays in our contemporary society involve a specific adaptation in the university way of teaching for future experts. Therefore, lecturers are using new teaching tools, such as clickers, in order to create an interactive learning environment and also improve student learning. The implementation of the European Higher Education Area has also boost changes on the teaching methodologies using new technologies. However, this implementation needs a teaching reflection about what the present labour market demands: a significant learning. In this article, an innovative design is presented to demonstrate a virtual learning environmental interrelated with the use of clickers in the lecture room as an active learning methodology strategy. The aim of this paper is to test empirically whether the students using clickers have a positive attitude towards the process of learning. The teaching experience applied to the subject of Financial Accounting I is specifically described. The total sample is 77 students from Business Administration Degree, taught in English and in Spanish, and from Economics Degree. The questionnaire responses and a reflexive experience of the
\end{abstract}

\footnotetext{
${ }^{1}$ A preliminary version of this article was presented at EDULEARN12, 4th International Conference on Education and New Learning Technologies, Barcelona, Spain, July, 2-4, 2012.

${ }^{2}$ Corresponding author. Campus of Somosaguas. Building 6th, office 63. 28223 Pozuelo-de-Alarcón. Madrid. Spain. marcamacho@ccee.ucm.es. Tel.0034913942585 Fax.0034 913942381.
} 
lecturer conclude that clickers are an extra tool that helps to improve the comprehension and the attention in subjects due to the increase of motivation. Descriptive statistics, correlations and regressions are used to corroborate our results. Further research about learning styles, learning environmental and students' attitudes should be developed to generalize the results of this study.

Keywords: clickers, interactive learning tool, students' motivation, teaching innovation, higher education 


\section{Introduction}

Social, economic, cultural and technological changes are transforming the professional requirements demanded by current university students. Being ready for professional life nowadays includes knowing how to use technology, working in teams, knowing English as a lingua franca and mastering the required expertise for each profession (Tynjälä, 1999) as well as being prepared to work in a continuously changing environment. The Society of Knowledge demands a powerful learning atmosphere in universities with the purpose of developing "an education setting where the students' learning is the core issue and instruction is defined as learning-enhancing" (Dochy, Segers, Van Den Bossche \& Struyven, 2005, p. 42). That process results from applying active learning methodologies to the constructivist theory developed by Vygotsky (1962).

Today, university learners are digital native because they have grown up with computers and the Internet and are said to have a natural aptitude and high skill levels when using new technologies (Jones, Ramanau, Cross \& Healing, 2010). The learning process of digital natives and its implication is not the same for digital natives than for digital immigrants that "were born before 1980 and therefore have learned how to use email and other social technologies later in life" (Nedbal et al., 2012, p. 167). Learning strategies could be near to students' preferences because of technology. Indeed, there is a positive influence of technology on the teaching-learning process although there are also perils and risks (Brill \& Galloway, 2007). In consequence, many university lecturers are pressured into using new technologies in teaching. However, before adding some technology innovation to lectures, instructors should be conscious of the aims to be achieved with this innovation. In general, the objective of any teaching improvement is to promote effective learning in the classroom. Active learning, providing feedback, 
increasing attention span and motivation are the four learning principles that have been identified as valid concepts that promote effective learning in the classroom (Beatty, 2004; Nelson \& Hauck, 2008). According to Lepine et al. (2004), Holzinger et al. (2009) and our experience as lecturers, the basis for student learning is the motivation to learn. Intrinsic motivation has emerged as an important phenomena for educators - a natural wellspring of learning and achievement (Ryan \& Stiller, 1991). Because intrinsic motivation results in high-quality learning, "it is especially important to detail the factors and forces that engender versus undermine it" (Ryan \& Deci, 2000, p. 55).Students may or may not be motivated to work as an architect or auditor but they find that many subjects of those degrees are difficult, boring or "without sense" by themselves. That is why motivation to learn is a key factor for finishing their degree studies (Martin, 2009) and also a key predictor of university early dropout (Alvarez, Figuera \& Torrado, 2011). Lecturers should be alert to foster students not only to pass subjects but also to acquire enough knowledge to develop their professional careers, that is to say, to acquire significant learning.

Another aspect that should be taken into account about effective learning is the learning environment because students' perceptions of a good teaching environment influence them towards better learning through deep approaches to studying (Lizzio, Wilson \& Simons, 2002). For present students, an interactive learning environment is also important, otherwise they could feel bored (Barnes, Marateo \& Ferris, 2007) and this could affect negatively their learning process (Baker, D’Mello; Rodrigo \& Graesser, 2010). The salient feature of interactivity is 'responsiveness to the learner's action during learning' (Moreno \& Mayer, 2007), that is precisely the clicker's function we want to test in the present research according to contingent teaching (Draper \& Brown, 2004; Van de 
Pol, Volman \& Beishuizen, 2011). Broadly speaking, clicker devices ${ }^{3}$ are small handheld units (one per student) as a TV remote control with keys to press the correct answer to proposed multiple-choice questions, although to make then work it is also needed the instructor receiver and the specific software to organise the process of questions and answers. The traditional question/answer procedure in class with the participation of just one or two students is moving to the answers of all the students and a quick feedback for students and for teachers as well. Clickers are personal response systems that stimulate interactivity in class, among other benefits (for a deep and recent review of clickers, see Keough, 2012). Indeed, feedback operates as a strong source of motivation so it can be essential in learning (Cloes, Premuzak, \& Pieron, 1993; Koka \& Hein, 2003)

Bearing all these things in mind, the main goal of this paper is to show empirically the impact of the use of clickers in the lecture room as a working strategy of active learning methodology because predicting and improving student perceptions of clickers may help to ensure positive outcomes (Trew \& Nelsen, 2012). This paper's main contribution is the validation of a teaching technology (clickers) in order to improve the internal motivation of students to a better learning environment. Our starting point is to analyse whether the students' intrinsic motivation for using clickers may explain their subject's grades and also to know the factors that could impact on this process. Moreover, students' general perceptions of clickers are presented according to different factors such as gender, age or language of instruction.

${ }^{3}$ Clickers are also known as Personal Response Systems (PRS), Student Response Systems (SRS), Electronic Response Systems (ERS), zappers and Automated Response Systems (ARS), among others. 
The structure of this paper is as follows: firstly a literature review is offered from the point of view of clickers use in higher education; secondly, we focus on the context, the sample and the methodology to achieve our objective. Finally, we discuss the findings and present our conclusions and suggestions to improve use of clickers in the university as a teaching-learning process improvement.

\section{Clickers as a teaching tool}

Based on a social constructivist view of learning, this study assumes that subject knowledge and its understanding are significantly enhanced through human interaction (Brown, Collins \& Duguid, 1989; Driscoll, 2005; Vygostky, 1978). Many times, students' knowledge level cannot be selected by lecturers, so instructors must confront the issue of actively engaging students and sustaining their interest throughout a semester or a year. This problem is exacerbated with the fact that the new generation are digital learners (Robinson \& Ritzko, 2006) and that some subjects could be considered/perceived more difficult or 'boring' than others. In our experience, Financial Accounting I, together with Business Mathematics, has the lowest success rate in the Business Administration Degree in our School. Moreover, since students have whole semester's presentations and exercises at their disposal, the use of a virtual learning environment platform in higher education is seen by some of them as an e-teacher and classroom attendance may decrease (Camacho-Miñano, 2012). In general, instructors may use different strategies to encourage students' attendance and their engagement in order to encourage undergraduates' active learning. One of those tools is clickers.

Clickers have received considerable attention in the educational literature since 1985 as they can be used to promote active learning (Beatty, 2004). There are several papers reviewing the literature on the use of clickers, e.g. Caldwell (2007), Fies \& Marshall (2006), Kay \& LeSage (2009), Lantz (2010) or Keough (2012). Recently, 
several papers about the benefits and failures of clickers implementation in university classrooms have been published (Bachman \& Bachman, 2011; Blood \& Neel, 2008; Trees \& Jackson 2007; White, Delaney, Syncox, Akerberg \& Alter, 2011; among other). However, results are not conclusive.

As we have mentioned before, clickers work with three elements, apart from a computer, a screen and a projector: the remote controls (individual, one for each student), the computer software and the receiver (only one per class). It seems an easy teaching tool, however, instructors have to spend a lot of time and effort in order to implement this new technology. Hence, it is interesting to know students' perceptions about clickers. To explore the students' perception, our first research question is:

RQ1: What are the most relevant aspects of clickers as seen by university students?

Depending on the clickers' manufacturer, their capabilities can vary. However, clickers are, broadly speaking, an easy and quick assessment tool for many lecturers (Vila Martin et al., 2011) although there are other interesting uses, such as improving the classroom environment or increasing participation, among others (White et al., 2011). But, in spite of the many benefits (increasing students' motivation, attention, attendance, retention, feedback...), there are also different problems or challenges in their use (Trees \& Jackson, 2007; Vila Martin et al., 2011) so instructors should analyse the use of this tool in class according to an appropriate learning activity environment (White, Syncox \& Alters, 2011). Indeed, the recent reviews about clickers (such as Keough, 2012; Lantz, 2010) do not comprise any empirical studies about positive and negative intrinsic motivation of clickers and learning/engagement students' perceptions. This paper has the aim to fill in this gap. Therefore, the research question here is:

RQ2: Do students perceive clickers as a learning tool? 
In spite of the research already done, 'more empirical studies are needed to examine the effectiveness of using technological innovations such as clickers in enhancing student learning' (Johnson \& Lillis, 2010). This is why this paper would like to bring to light empirical evidence about the use of clickers with university students.. Classroom response systems have been incorporated into a standard lecture course to encourage students to study, to increase the students-instructor interaction, to facilitate the understanding of theoretical concepts into practice and used them as part of a more radical change in the teaching style towards an active learning in class. The idea is to persuade students/lecturers to use clickers because we think this is the way to have more motivation to study any subject.

In general, our hypothesis is that students that are more motivated to use clickers have better grades. In consequence, other research questions of this study are the following:

RQ3: Is there any relationship between the intrinsic motivation of using clickers and the student grades?

RQ4: What factors could explain the grades of students that use clickers in class?

In the following sections, we answer all previous four questions that are essential for a good implementation of this interactive tool not only for instructors but also for learners.

\section{The study}

\section{Procedure}

Classes were held twice a week and each class was of around one hour and fifty minutes. The course instruction and data collection were run by the lecturer of the subject. The duration of the course was fourteen weeks and there were seven chapters in the syllabus. 
Students were instructed on how to use the clickers the first day of the course. Due to our past experience using clickers (six academic courses), it is essential to create a learning climate about this technology because many students could think they are "playing a game' while they are using them. Even this first day, students already used clickers in order to be familiar with them. Some routine questions were used to check if students understood the learning device handling. Then the clickers were used throughout all the theoretical parts of the semester to answer in-class multiple-choice questions presented during lectures with the use of PowerPoint. Depending on the nature of each chapter (more or less practical), there could be between ten to forty-one questions per chapter with a totalof more than 150 for the entire course ${ }^{4}$. All questions were multiple-choice with four possible answers but only one correct ${ }^{5}$. All the questions and answers were built by the teacher of the subject. One by one, the instructor also programmed the correct answer through the system software. In addition to the question and the possible answers, each slide had a chart at the bottom of the PPT with the following information: (see Figure 1)

Figure 1 near here

- Several small squares with a number (each number is linked with a remote control) as many as students attending the lecture the day of each presentation. When the

\footnotetext{
${ }^{4}$ The first and the last chapters had 10 and 12 (?) questions, respectively, while the other chapters had less questions.

${ }^{5}$ There are many proposals about preparing quizzes. According to our experience, most of our questions are presented in a negative way in order to make students read three correct answers and only one wrong. At the same time those students read, they are really learning about the question topic.
} 
student chooses the answer, the square with the associated number of his/her remote control changes its colour in the screen.

- $\quad$ On the right, there is information about the number of students that have already voted, the time left and already consumed and another small square with the option to stop or to continue the 'voting process'.

- When the 'voting process' finishes, the squares with the numbers representing each student disappear and the aggregated results of the students' answers appear. The questions and the answers are anonymously displayed in a histogram, red ones as wrong answers and green one only for the correct one.

Depending on the setting-up of the system, there are three different ways ${ }^{6}$ to present the results. In order to avoid pressure and fear of embarrassment meanwhile students are learning new concepts, the instructor explained to them that there was no assessment purpose using clickers so the setting used was without data capture.

Questions were embedded into PowerPoint lecture slides displayed on a projection screen without a fixed sequence. It means that if the teacher wanted to introduce a new accounting concept, for example a definition of asset ${ }^{7}$ as 'a resource controlled by the enterprise as a result of past events and from which future economic

${ }^{6}$ In Educlick systems, there are three specific configurations: without data capture (anonymous), data capture by group (all the class together) and data capture by students (individually).

${ }^{7}$ According to the International Accounting Standards Board (IFRS) Framework. IFRS for SME. Par. 49a. 
benefits are expected to flow to the enterprise', then three quizzes ${ }^{8}$ were presented in order to understand this concept in real business. When each quiz appeared, students were given between forty to fifty seconds to read and answer it. Once the teacher stopped the time, no more answers were allowed by the system. Then, the teacher read aloud the question and, sometimes, one person was challenged to choose the right answer. Sometimes, interesting peer-to-peer or lecturer-to-student debates appeared in class in order to clarify the correct answer. Proportionally to the number of right or wrong questions out of number of votes, four horizontal bars (as a histogram) were shown but three in red colour that means that they were wrong answers and only one horizontal bar in green colour, that means this is the correct answer. Depending on the size of each red bar, the teacher explained again why those were not correct. This means that students receive almost instant feedback about their understanding of new theoretical concepts about the subject and, what it is more important, the real implementation ${ }^{9}$ of those concepts in particular business (bookshops, travel agencies, manufacturer companies...). Moreover, this quick feedback is also essential for the teacher because if more than $50 \%$ of the class answered the question incorrectly, the teacher spent more time explaining the concept linked to the question answered wrongly by the majority of the class. This is also

\footnotetext{
${ }^{8}$ Those three questions are: Which of the following elements is an asset for a bookshop?; An automobile manufacturer presents this information. Which is NOT an asset for this business? Which one of these following items could never be an asset in the financial statement of a service company?

${ }^{9}$ In accounting subjects, the business type is a really important key because it is not the same book-keeping for a service company as for a manufacturer or a merchandise one. (For more information see Camacho, Akpinar, Rivero, Urquia \& Escola, 2012).
} 
important in financial accounting subject because the accounting knowledge is summative, that is, the former basic concepts are used to build the last one. For example, if students cannot distinguish what element is an asset then they will prepare the balance sheet with wrong contents because all the assets of a company belong to the balance sheet. A situation like the previously mention made the lecturer increases the number of questions proposed in class to clarify the accounting concepts as some students may wonder why his or her answer did not correspond with the correct answer provided by the systems.

\section{Context and Sample}

The sample used in this study is from the Complutense University of Madrid (UCM), the largest university in Spain with almost 85,000 students and over 6,000 lecturers (http://www.ucm.es). During the academic year 2011-2012, this university offered 75 different undergraduate degrees and 130 official master's degrees and doctoral programmes.

Financial Accounting I (FAI) is a common subject to the first year of the Business Administration (BBA) and the Economics (BE) degrees. Around 700 students were enrolled in FAI distributed in eight sections belonging to the BBA and seven to the $\mathrm{BE}$ among which two are taught in English, one for each degree. The student sample is a convenience sample formed by the three groups, out of those 17 , taught by the same lecturer, using the same methodology and clickers system to avoid lecturer bias. In concrete, there are two belonging to BBA (one of them in English) and one belonging to the BE.

The total sample number is 77 students for the introduction course to Financial Accounting. 28 students (35.9\% of the total sample) belong to the Business 
Administration Degree taught in Spanish, 22 students (28.2\%) were from the same degree but taught in English and 27 students (34.6\%) were from the Economics degree taught in Spanish as well. $41 \%$ of the total sample is male and the mean age is 19.21 years old (range: $18-22$ ). $70.1 \%$ of the students are enrolled within their age, that is, they are not students repeating by a year. Additionally, none of the students involved in the study had prior experience with the clicker technology. One interesting characteristic of the study sample is that there is the same self-reported percentage of students that failed the middleterm exam (closed-book and time pressure) as students that passed it (34.6\%), as Figure 2 shows, according to their self-recording grade. The other $29.5 \%$ of the total sample passed with honours (more than 7 out of 10) the previously mentioned examination. Absolute frequencies of 'pass' and 'pass with honours' for the real middle-term exam are practically equal, while for those who failed only 26 out of the original 84 where in class the day the survey was done. The authors assume those are drop-outs.

Figure 2 near here

\section{Data gathering and methodology}

An 'ad-hoc' pen and paper survey of 33 items was divided into four sections for the research questions to be answered, as follows. The first section requested demographic data (gender, age and group) and the grade for the middle-term exam of the subject. Because anonymity is one of the strength of surveys (Powell, 2003), the previously mentioned midterm exam grade was self-reported in spite of the possibility of misleading.

The second section of the questionnaire had two questions about positive and negative aspects of clickers following Doucet, Vrins \& Harvey (2009). There are five possible answers but only one option is permitted. 
The third section of the questionnaire was about clickers' classroom experiences. Using a five-point Likert-type scale, five items assessed students' perceptions and behaviours related to the learning processes, according to Trees \& Jackson (2007). There were five sentences for "learning items" that assess students' perceptions and behaviours related to learning processes. And six sentences for "engagement items" that assess student' perceptions of and reported behaviours regarding active involvement in the class.

Finally, related to the students' intrinsic motivation to use clickers as a teaching tool, the last section of the questionnaire was the Intrinsic Motivation Inventory (IMI) tested in several experiments (i.e. Deci, Eghrari, Patrick \& Leone, 1994; Ryan, 1982; Tsigilis \& Theodosiou, 2003). It has six subscales although the interest/enjoyment subscale is considered the self-report measure of intrinsic motivation, that is, the only subscale that assesses intrinsic motivation per se. Moreover, a pressure/tension subscale is used in order to analyse a negative predictor of intrinsic motivation. So the 12 -item version of interest/enjoyment and pressure/tension version was used in this study about students' subject motivation. All the sentences should be marked from 1 (not at all true) to 7 (very true). There are some sentences identified with the capital letter $\mathrm{R}$, meaning that the score must be reversed, subtracting the item response from eight and using the resulting number as the item score.

The survey ${ }^{10}$ was administered during class on the last day of the semester and closed in an envelope until the end of the year in order to avoid pressure in the answers due to the final exam grades. Previously, the instructor explained the objective of the research and the procedure. The survey was anonymous and none of the students in class refused to answer the questionnaire.

\footnotetext{
${ }^{10}$ You can access this study survey and answers writing to marcamacho@ccee.ucm.es.
} 
Statistical methods such as descriptive statistics, correlations and logistic regression are used to answer the research questions proposed.

\section{Results and discussion}

The most relevant positive and negative aspects of clickers have been tested in order to answer the first research question, $48.7 \%$ of students consider positively the fact that with clickers they are able to self-evaluate their knowledge of the subject (see Table 1) and a $23.1 \%$ the fact that clickers help them understand accounting concepts. So more than two thirds of the students consider that the most positive aspect of clickers is directly related to the comprehension of the subject concepts. These perceptions play an important role in its effectiveness (Trew \& Nelsen, 2012).

Table 1 near here

However, asking about the negative aspects of the tool, most students thought that the tool needs to be complemented with more explanations than the lecturer made during its use (see Table 2). It should be pointed out that more than $16 \%$ of students did not consider that the use of clickers in class had any negative aspect. This result differs from Doucet et al. (2009) and it may be due to cultural aspects from one student to another. More multi-cultural studies are needed to generalize conclusions.

Table 2 near here

In relation to the second research question, the perception of the students in the sample about clickers is interesting because, in general, there is not too much enthusiasm about this tool even though there is no other lecturer using it with the same groups of students. As it is shown in Table 3, the most important results are that clickers helped them to learn the subject because students are interested in answering correctly and also in learning from the answer solutions. Our mean (from L1 to L5) is higher than Trees \& Jackson (2007)'s paper (3.76; $\mathrm{SD}=0.95)$ so it means than higher scores reflect more 
positive assessment. This is very important as clickers may be a good motivator for learning. In spite of it, the active participation in class is also measured (from E1 to E6) although our results are lower than Trees \& Jackson (2007)'s paper (3.28; SD=0.82). It may mean that the students of our sample have less engagement perhaps due to the immaturity or less university class experience of the first-year university students.

Table 3 near here

The third research question is about the intrinsic motivation of using clickers for first-year accounting students. As presented in the literature, this kind of student has particular characteristics as 'the first year is a crucial stage in the process of socialisation into the undergraduate role and the highly sensitive touchstone for the quality of the student experience' (Reason, Terenzini \& Domingo, 2006). That is why it is interesting to analyse the intrinsic motivation to use a new learning tool.

The first result of students' perceptions about clickers is that they are very motivated towards using clickers as the mean interest of clickers is 5.16 out of 7 (see Table 4). This is an interesting result because enjoyment using clickers is in line with pedagogical theories in order to effectively teach and learn (Blunsdon, Reed, McNeil \& McEachern, 2003; Ebner \& Holzinger, 2007).

Another important issue to take into account about the implementation of clickers is the pressure on students (Kay \& LeSage, 2009; Lin, Liu \& Chu, 2011; MacArthur \& Jones, 2008). In particular, some of the critics to clickers are related to the stress of using them in class, even if the students are not given marks due to the need of understanding new concepts and participating in the class debates. However, in our study, students' pressure with clickers is not significant because the mean is 2.07 out of 7 , with a standard deviation below 1 (see Table 4). Our results are in line with the literature (Latessa \& Mouw, 2005; Plant, 2007). 
Table 4 near here

Nevertheless, there is no relationship between the intrinsic motivation to use clickers and grades as there are no significant correlations (see Table 5). Hence, grades are not significantly related to the intrinsic motivation to use clickers in class. But, as we have mentioned before, grades were self-reported so the students may cheat and this could be an explanation about this results. In any case, our results are in line with other studies (e.g. Baumberger-Henry, 2010; Mula \& Kavanagh, 2009).

Regarding the success rate ${ }^{11}$ of the subject, it was $57 \%$ in the $2006 / 07$ academic year while it was $74.5 \%$ in the academic year of this experiment. Taking into account the number of students enrolled officially, the efficiency rate was $48 \%$ and $63 \%$, respectively, meaning that the drop-out number of students has decreased maybe because the use of clickers gives better feedback and improves attention to theoretical explanations making the subject more attractive.

Table 5 near here

What is more, if we link the interest or enjoyment of clickers with student grades, those students who failed the first financial accounting exam had had less fun although, curiously, they are also the ones with less pressure when using them (see Table 6). This could be because they have less to "lose" due to their fewer hours of study. However, outstanding students do not really have a good perception of clickers because they are

${ }^{11}$ We mean by success rate of a subject the ratio of the number of students that pass a subject divided by the number of students that are evaluated, while efficiency rate is the ratio of the number of students that pass a given subject divided by the number of students enrolled on that subject. 
really motivated by themselves but they also feel less pressured than students who pass without honors.

Table 6 near here

In relation to research question four, looking for the relationship between variables (see Table 7) there is a significant positive correlation between active participation and grades, although it is not connected to gender. Another implication between variables is that feedback is significantly correlated to learning items such as the fact that clickers help students to know how well they were learning the material (L2), are helpful for preparing them for the exams in class (L3), for choosing answers to each clicker question carefully (L4) and for paying attention to whether or not their answer to a clicker question was correct (L5). Finally, the discussion in class is significantly statistically correlated to the use of clickers in class that made students feel less anonymous (E4) and work more seriously (E5).

Table 7 near here

Multinomial logit models are used to model relationships between a response variable with more than two categories and a set of regressor variables. This method is very useful to understand the effect of a series of variables, in our case the Learning and Engagement Items, on an unordered qualitative response variable, in our case the first FA mark.

Table 8 near here

Table 9 near here

Several indicators on the model's goodness of fit are given in Tables 8 and 9. All three pseudo R-square values, McFadden, Cox \& Snell and Nagelkerke (see Table 8) are highly satisfactory. But the most important value to look at is the probability of the Chi- 
square test on the log ratio (see Table 9). In this case, as the probability is lower than 0.01 , we can conclude that significant information is provided by the variables.

Details on the model with the Learning and Engagement items as independent variables are shown in Table 10. This table is helpful in understanding the effect of the various variables on the categories of the response variable (first FA mark). Parameters are obtained for each category of the response variable (except the reference category which in our case is category 0). Odds ratios are also given for a better understanding of the results. Variable 'age' was excluded from the model as it was not significant.

Table 10 near here

By looking at the probability of the Chi-squares on the remaining variables, we see that the variables that most influence the response variable for both categories (1=pass, 2=pass with honours) are 'interest/enjoyment', 'pressure', L1, E5 and negative aspects of clickers (aggregated values of variables, see Table 2) except E1 that influences only the category 2. The intercepts are significant but neither are the Age nor the Gender, so neither of them influences the first FA mark.

\section{Conclusions}

The objective of this research was to show empirical evidence of the students' attitude towards the process of learning, using clickers as a useful teaching tool. In general they find clickers help them to learn the subject and get feedback and this interaction is essential in a learning environment today (Brna \& Lucking, 2008). Indeed students perceive clickers positively to understand the theoretical questions of the subject. And this is a basic issue in accounting as there are some terms that have different meanings if they are used in everyday life or in accounting area (Moreno Alemany, 2008). However, instructors should realize the negative student perceptions and enhance explanations. 
Clickers are a good learning tool for university students because the system improves classroom dynamics so they are more motivated to learn. Therefore, learning is effective (Bojinova \& Oigara, 2011). The most significant perception of freshmen students is that they enjoy clickers whilst they learn accounting. Hence lecturers could stimulate student enjoyment by using clickers, while fostering learning. On the other hand, there is no relationship with grades. In general, students are satisfied using clickers as a learning tool although negative aspects such as more feedback explanations are needed to get better results.

Finally, there are several factors (like feedback to understand or to help to learn or anonymity) that influence the final mark for those students using clickers, but neither of them are gender or age.

However, there are limitations to consider in interpreting our findings. Firstly, the sample size posed some challenges when interpreting data and the data presented in this study are all self-reported. Tracking the same students over time and assessing factor structure and interrelationships from a longitudinal perspective would shed further light on the developmental processes relevant to motivation. Secondly, the nature of quantitative survey-based methods is also limited. Future research might encompass qualitative work that can fully reveal the detailed nature and extent of motivation across the academic life span. In addition, we will try to improve the teaching methodology by implementing, for example, the peer instruction (Mazur, 1997) or the Dufresne sequence for classroom communication (Dufresne, Gerace, Leonard, Mestre and Wenk, 1996) to foster conceptual understanding and communication in class.

\section{References}

Alvarez González, M., Figuera Gazo, P., \& Torrado Fonseca, M. (2011). La problemática de la transición ballicherato universidad en la Universidad de Barcelona [The 
problematic of the transition from the high school to the university in the Barcelona University]. REOP, 22 (1), 15-27.

Bachman, L., \& Bachman, C. (2011). A study of classroom response system clickers: Increasing student engagement and performance in a large undergraduate lecture class on architectural research. Journal of Interactive Learning Research, 22, 521.

Baker, R.S., D’Mello, S.K., Rodrigo, M.T., \& Graesser, A.C. (2010). Better to be frustrated than bored: The incidence, persistence, and impact of learners' cognitive-affective states during interactions with three different computer-based learning environments. International Journal of Human-Computer Studies, 68, 223-241.

Barnes, K., Marateo, R. C., \& Ferris, S. P. (2007). Teaching and learning with the net generation. $\quad$ Innovate, $3 . \quad$ Retrieved from http://www.innovateonline.info/index.php?view=article\&id=382

Baumberger-Henry, M. (2010). Student Response Systems: How Effective are they on Student Outcomes?. STTI International Nursing Research Congress, Retrieved from http://hdl.handle.net/10755/152090.

Beatty, I. (2004). Transforming student learning with classroom communication systems. Educause Research Bulletin, 3, 2-13.

Blood, E., \& Neel, R. (2008). Using Student Response Systems in Lecture-Based Instruction: Does It Change Student Engagement and Learning?. Journal of Technology and Teacher Education, 16, 375-383.

Blunsdon, B., Reed, K., McNeil, N., \& McEachern, S. (2003). Experiential learning in social science theory: an investigation of the relationship between student enjoyment and learning. Higher Education Research and Development, 22, 4356.

Brna, P., \& Lucking, R. ( 2008). Narrative and interactive learning environments. Interactive Learning Environments, 16, 195-197.

Bojinova, E., \& Oigara, J.N. (2011). Teaching and Learning with clickers: are clickers good for students?. Interdisciplinary Journal of E-Learning and Learning Objects, 7, 1-16.

Brill, J.M., \& Galloway, C. (2007). Perils and promises: university instructors' integration of technology in classroom-based practices. British Journal of Educational Technology, 38, 95-105. 
Brown, J.S., Collins, A., \& Duguid, P. (1989). Situated cognition and the culture of learning. Educational Researcher, 18, 32-42.

Caldwell, J.E. (2007). Clickers in the large classroom: current research and best-practice tips. Life Sciences Education, 6, 9-20.

Camacho-Miñano, M.M. (2012). El uso de mandos interactivos: una innovación docente para aumentar la motivación y mejorar el aprendizaje del alumnado universitario [The use of clickers: a teaching innovation to increase the motivation and to improve learning of undergraduate students]. Revista TESI, 13, 412-436.

Camacho-Miñano, M.M., Akpinar, M., Rivero, M.J., Urquia, E., \& Escola, A. (2012). Beyond figures: Introduction to Financial Accounting. Madrid. Ed. Pirámide.

Cloes, M., Premuzak, J., \& Pieron, M. (1993). Effectiveness of a video training programme used to improve error identification and feedback processes by physical education teachers. International Journal of Physical Education, 32(3), $4-9$.

Deci, E. L., Eghrari, H., Patrick, B. C., \& Leone, D. (1994). Facilitating internalization: The self-determination theory perspective. Journal of Personality, 62, 119-142

Dochy, F., Segers, M., Van Den Bossche, P., \& Struyven, K. (2005). Students' perceptions of a problem-based learning environment. Learning Environments Research, 8, 41-66.

Doucet, M., Vrins, A., \& Harvey, D. (2009). Effect of using an audience response system on learning environment, motivation and long-term retention, during casediscussions in a large group of undergraduate veterinary clinical pharmacology students. Medical Teacher, 31, 570-579.

Draper, S.W., \& Brown, M.I. (2004). Increasing interactivity in lectures using an electronic voting system. Journal of Computer Assisted Learning, 20, 81-94.

Driscoll, M. P. (2005). Psychology of learning for instruction (3rd ed.). Boston: Pearson.

Dufresne, R.J.; Gerace, W. J.; Leonard, W.J.; Mestre, J. P. \& Wenk, L. (1996). Classtalk: a Clasroom communicatin system for active learning. Journal of Computing in Higher Education, 7, 3-47.

Ebner, M., \& Holzinger, A. (2007). Successful Implementation of User-Centered Game Based Learning in Higher Education - an Example from Civil Engineering. Computers \& Education, 49, 873-890 
Fies, C., \& Marshall, J. (2006). Classroom response systems: a review of literature. Journal of Science Education and Technology, 15, 101-109.Holzinger, A., Kickmeier-Rust, M., Wassertheurer, S., \& Hessinger, M. (2009). Learning Performance with Interactive Simulations in Medical education: Lessons learned from results of learning complex physiological models with the HAEMOdynamics SIMulator. Computers \& Education, 52(1), 292-301.

Johnson, K., \& Lillis, C. (2010). Clickers in the laboratory: student thoughts and views. Interdisciplinary Journal of Information, Knowledge and Management, 5, 139151.

Jones, C., Ramanau, R., Cross, S., \& Healing, G. (2010). Net generation or digital natives: is there a distinct new generation entering university?. Computers \& Education, $54,722-732$.

Kay, R.H., \& LeSage, A. (2009). Examining the benefits and challenges of using audience response systems: A review of the literature. Computers \& Education, 53, 819827.

Keough, S.M. (2012). Clicker in the classroom: a review and a replication. Journal of Management Education, DOI: 10.1177/1052562912454808. 1-26.

Koka, A., \& Hein, V. (2003). Perceptions of teacher's feedback and learning environment as predictors of intrinsic motivation in physical education. Psychology of Sport and Exercise, 4, 333-346

Lantz, M.E. (2010). The use of "clickers" in the classroom: teaching innovation or merely an amusing novelty?. Computers in Human Behavior, 26, 556-561.

Latessa, R., \& Mouw, D. (2005). Use of an audience response system to augment interactive learning. Family Medicine, 37, 12-14.

LePine, J. A., LePine, M. A., \& Jackson, C. L. (2004). Challenge and hindrance stress: relationships with exhaustion, motivation to learn, and learning performance. Journal of Applied Psychology, 89, 883-891.

Lin, Y.C., Liu, T.C., \& Chu, C.C. (2011). Implementing clickers to assist learning in science lectures: the clicker-assisted conceptual change model. Australasian Journal of Educational Technology, 27, 979-996.

Lizzio, A., Wilson, K., \& Simons, R. (2002). University Students' Perceptions of the Learning Environment and Academic Outcomes: implications for theory and practice. Studies in Higher Education, 27, 27-52. 
Martin. A.J. (2009). Motivation and engagement across the academic life span. A developmental construct validity study of elementary school, high school, and university/college Students. Educational and Psychological Measurement, 69, 794-824.

MacArthur, J. R., \& Jones, L. L. (2008). A review of literature reports of clickers applicable to college chemistry classrooms. Chemistry Education Research and Practice, 9, 187-195.

Mazur, E. (1997). Peer Instruction: A User's Manual. Upper Saddle River, N.J.: Prentice Hall.

Moreno Alemany, P. (2008). English content-based approaches to teaching accounting. Latin American Journal of Content and Language Integrated Learning, 1(1), 2634.

Moreno, R., \& Mayer, R. (2007). Interactive multimodal learning environments. Educational Psychology Review, 19, 309-326.

Mula, J.M., \& Kavanagh, M. (2009). Click go the students. click-click-click: the efficacy of a student response system for engaging students to improve feedback and performance. E-Journal of Business Education and Scholarship of Teaching, 3, $1-17$.

Nelson, M.L., \& Hauck, R.V. (2008). Clicking to learn: a case study of embedding radiofrequency based clickers in an introductory management information systems course. Journal of Information Systems Education, 19, 55-64.

Plant, J.D. (2007). Incorporating an audience response system into veterinary dermatology lectures: effect on student knowledge retention and satisfaction. Journal of Veterinary Medical Education, 34, 674-677.

Powell, C. (2003). The Delphi technique: myths and realities. Journal of Advanced Nursing, 41, 376-382.

Reason, R.D., Terenzini, P.T., \& Domingo. J.R. (2006). First things first: developing academic competence in the first year of college. Research in Higher Education, 47, 149-175.

Robinson, S., \& Ritzko, J. (2006). Increasing student engagement through electronic response devices. Proceedings of the Academy of Educational Leadership, 11, 7982. 
Ryan, R. M. (1982). Control and information in the intrapersonal sphere: An extension of cognitive evaluation theory. Journal of Personality and Social Psychology, 43, 450-461.

Ryan, R. M., \& Deci, E.L. (2000). Intrinsic and extrinsic motivations: classic definitions and new directions. Contemporary Educational Psychology, 25, 54-67.

Ryan, R. M., \& Stiller. J. (1991). The social contexts of internationalization: parents and teacher influences on autonomy, motivation and learning. In P.R. Pibtrich \& M.L. Maehr Advances in motivation and achievement, 7. Goals and self-regulating process (pp. 115-149) Greenwich, CT: JAI Press.

Trees, A. R., \& Jackson, M.H. (2007). The learning environment in clicker classrooms: student processes of learning and involvement in large university-level courses using student response systems. Learning, Media and Technology, 32, 21-40.

Trew, J.L., \& Nelsen, J.L. (2012). Getting the most out of audience response systems: predicting student reactions. Learning, Media and Technology, 37, 379-394.

Tsigilis, N., \& Theodosiou, A. (2003). Temporal stability of the Intrinsic Motivation Inventory. Perceptual and Motor Skills, 97, 271-280.

Tynjälä, P. (1999). Towards expert knowledge? A comparison between a constructivist and a traditional learning environment in the university. International Journal of Educational Research, 31, 357-442.

Van de Pol, J., Volman, M., \& Beishuizen, J. (2011). Patterns of contingent teaching in teacher-student interaction. Learning and Instruction, 21, 46-57.

Vila Martin, H., Garcia Palacios, A., Osma López, J., Mezquita Guillamon, L., Ortet Fabregat, G., Ibañez Ribes, M.I., ... Moro Ipola, M. (2011). Continuous assessment with the use of an electronic response system. Proceedings EDULEARN11. http://library.iated.org/view/VILLAMARTIN2011CON

Vygotsky, L.S. (1962). Thought and Language. Cambridge. MA: MIT Press.

Vygotsky, L. (1978). Mind in society. Cambridge. MA: Harvard University Press.

White, P.J.T., Delaney, D.G., Syncox, D., Akerberg, O.A., \& Alters, B. (2011). Clicker implementation models. EDUCAUSE Review online, Retrieved from http://www.educause.edu/ero/article/clicker-implementation-models.

White, P., Syncox, D., \& Alters, B. (2011). Clicking for grades? Really? Investigating the use of clickers for awarding grade-points in post-secondary education. Interactive Learning Environments, 19, 551-561. 
Table 1. Positive aspects of clickers in class

\begin{tabular}{|ll|l|l|}
\hline & Frequency & Percent \\
\hline Valid & It is fun & 3 & 3.8 \\
& It is very interactive & 14 & 17.9 \\
I am able to auto-evaluate my knowledge & 38 & $\mathbf{4 8 . 7}$ \\
$\quad$ of the accounting subject & & \\
It helps me to retain the subject & 4 & 5.1 \\
It helps me to understand the accounting \\
$\quad$ concepts & 18 & 23.1 \\
Total & 77 & \\
Missing & System & 1 & 98.7 \\
Total & & 1.3 \\
\end{tabular}


Table 2. Negative aspects of clickers in class

\begin{tabular}{|ll|l|l|}
\hline & & Frequency & Percent \\
\hline Valid & It is difficult & 4 & 5.1 \\
& It is long & 8 & 10.3 \\
& It lacked explanations & 51 & $\mathbf{6 5 . 4}$ \\
& It is not pertinent & 2 & 2.6 \\
& Total & 65 & 83.3 \\
Missing & System & 13 & 16.7 \\
Total & & 78 & 100.0 \\
\hline
\end{tabular}


Table 3. Descriptive statistics about learning and engagement items of clickers

\begin{tabular}{|c|c|c|c|c|c|}
\hline & & Min & Max & Mean & $\begin{array}{l}\text { Std. } \\
\text { Dev. }\end{array}$ \\
\hline L1 & $\begin{array}{l}\text { By using clickers in this class, I got feedback } \\
\text { on my understanding of class material }\end{array}$ & 1 & 6 & 3.57 & 1.056 \\
\hline L2 & $\begin{array}{l}\text { Clicker questions helped me to know how well } \\
\text { I was learning the material }\end{array}$ & 2 & 7 & 4.07 & .951 \\
\hline L3 & $\begin{array}{l}\text { Clicker questions were helpful for preparing } \\
\text { me for the exams in class. }\end{array}$ & 1 & 7 & 3.80 & 1.027 \\
\hline L4 & $\begin{array}{l}\text { I choose my answer to each clicker question } \\
\text { carefully. }\end{array}$ & 1 & 7 & 4.03 & 1.013 \\
\hline \multirow[t]{2}{*}{ L5 } & $\begin{array}{l}\text { I pay attention to whether or not my answer to } \\
\text { a clicker question was right or wrong. }\end{array}$ & 2 & 7 & 4.60 & .988 \\
\hline & LEARNING ITEMS & & & 3.96 & \\
\hline E1 & $\begin{array}{l}\text { Clicker questions encouraged me to be more } \\
\text { engaged in the classroom process. }\end{array}$ & 1 & 7 & 3.78 & 1.059 \\
\hline E2 & I actively participate during class & 1 & 5 & 3.57 & 1.043 \\
\hline E3 & $\begin{array}{l}\text { The use of clickers helped my experience in } \\
\text { this class to be more like the experience of } \\
\text { a small class }\end{array}$ & 1 & 7 & 3.09 & 1.338 \\
\hline E4 & $\begin{array}{l}\text { The use of clickers in this class has made me } \\
\text { feel less anonymous }\end{array}$ & 1 & 6 & 2.57 & 1.358 \\
\hline E5 & $\begin{array}{l}\text { Sometimes during a class. Students were asked } \\
\text { to discuss material with each other. } \\
\text { Because the class used clickers. We } \\
\text { discussed the material more seriously. }\end{array}$ & 1 & 6 & 2.97 & 1.275 \\
\hline \multirow[t]{2}{*}{ E6 } & $\begin{array}{l}\text { Often I feel withdrawn or distant during } \\
\text { interactions in this class. }\end{array}$ & 1 & 5 & 2.32 & 1.213 \\
\hline & ENGAGEMENT ITEMS & & & 2.98 & \\
\hline
\end{tabular}


Table 4. Descriptive Statistics

\begin{tabular}{|c|c|c|c|c|c|}
\hline & $\mathrm{N}$ & Min & Max & Mean & $\begin{array}{l}\text { Std. } \\
\text { Dev. }\end{array}$ \\
\hline I enjoyed using of clickers very much & & 1 & 7 & 5.10 & 1.535 \\
\hline The use of clickers was fun to do & & 1 & 7 & 5.34 & 1.363 \\
\hline I thought the use of clickers was a boring activity $(\mathrm{R})$ & & 2 & 7 & 6.12 & 1.124 \\
\hline The use of clickers did not hold my attention at all (R) & & 2 & 7 & 5.97 & 1.235 \\
\hline I would describe the use of clickers as very interesting & & 1 & 7 & 4.94 & 1.417 \\
\hline I thought the use of clickers was quite enjoyable & & 2 & 7 & 5.22 & 1.284 \\
\hline $\begin{array}{l}\text { While I was using the clickers, I was thinking about how } \\
\text { much I enjoyed it }\end{array}$ & & 1 & 7 & 3.44 & 1.902 \\
\hline INTEREST/ENJOYMENT & 77 & & & 5.162 & 1.0692 \\
\hline $\begin{array}{l}\text { I did not feel nervous at all while using clickers (R) } \\
\text { I felt very tense while using clickers } \\
\text { I was very relaxed in using clickers (R) } \\
\text { I was anxious while working on this task } \\
\text { I felt pressured while using clickers }\end{array}$ & & $\begin{array}{l}1 \\
1 \\
1 \\
1 \\
1\end{array}$ & $\begin{array}{l}7 \\
7 \\
7 \\
7 \\
6\end{array}$ & $\begin{array}{l}2.29 \\
1.61 \\
2.74 \\
1.88 \\
1.84\end{array}$ & $\begin{array}{l}1.898 \\
1.258 \\
1.963 \\
1.357 \\
1.182 \\
\end{array}$ \\
\hline PRESSURE/TENSION & 77 & & & 2.073 & .9597 \\
\hline
\end{tabular}


Table 5. Correlations between grades, interest and pressure of clickers

\begin{tabular}{|ll|l|l|l|}
\hline & & $\begin{array}{l}\text { SUBJECT } \\
\text { GRADE }\end{array}$ & $\begin{array}{l}\text { INTEREST/ } \\
\text { ENJOYMENT }\end{array}$ & $\begin{array}{l}\text { PRESSURE/ } \\
\text { TENSION }\end{array}$ \\
\hline SUBJECT GRADE & $\begin{array}{l}\text { Pearson Correlation } \\
\text { Sig. (2-tailed) }\end{array}$ & 1 & & \\
& Pearson Correlation & .138 & 1 & \\
\hline INTEREST/ENJOYMENT & Sig. (2-tailed) & .239 & & \\
\hline PRESSURE/TENSION & $\begin{array}{l}\text { Pearson Correlation } \\
\text { Sig. (2-tailed) }\end{array}$ & .097 & -.009 & 1 \\
& Sig & .936 & \\
\hline
\end{tabular}


Table 6. Relation between intrinsic motivation and subject grades

\begin{tabular}{|c|c|c|c|c|}
\hline & & $\mathrm{N}$ & Mean & $\begin{array}{l}\text { Std. } \\
\text { Dev. }\end{array}$ \\
\hline \multirow[t]{3}{*}{ INTEREST/ENJOYMENT } & FAIL & 26 & 4.904 & .9480 \\
\hline & PASS & 26 & 5.358 & 1.0534 \\
\hline & PASS WITH HONORS & 23 & 5.248 & 1.1401 \\
\hline \multirow[t]{3}{*}{ PRESSURE/TENSION } & FAIL & 26 & 1.908 & .7467 \\
\hline & PASS & 26 & 2.215 & 1.0039 \\
\hline & PASS WITH HONORS & 23 & 2.130 & 1.1340 \\
\hline
\end{tabular}


Table 7. Correlations between variables

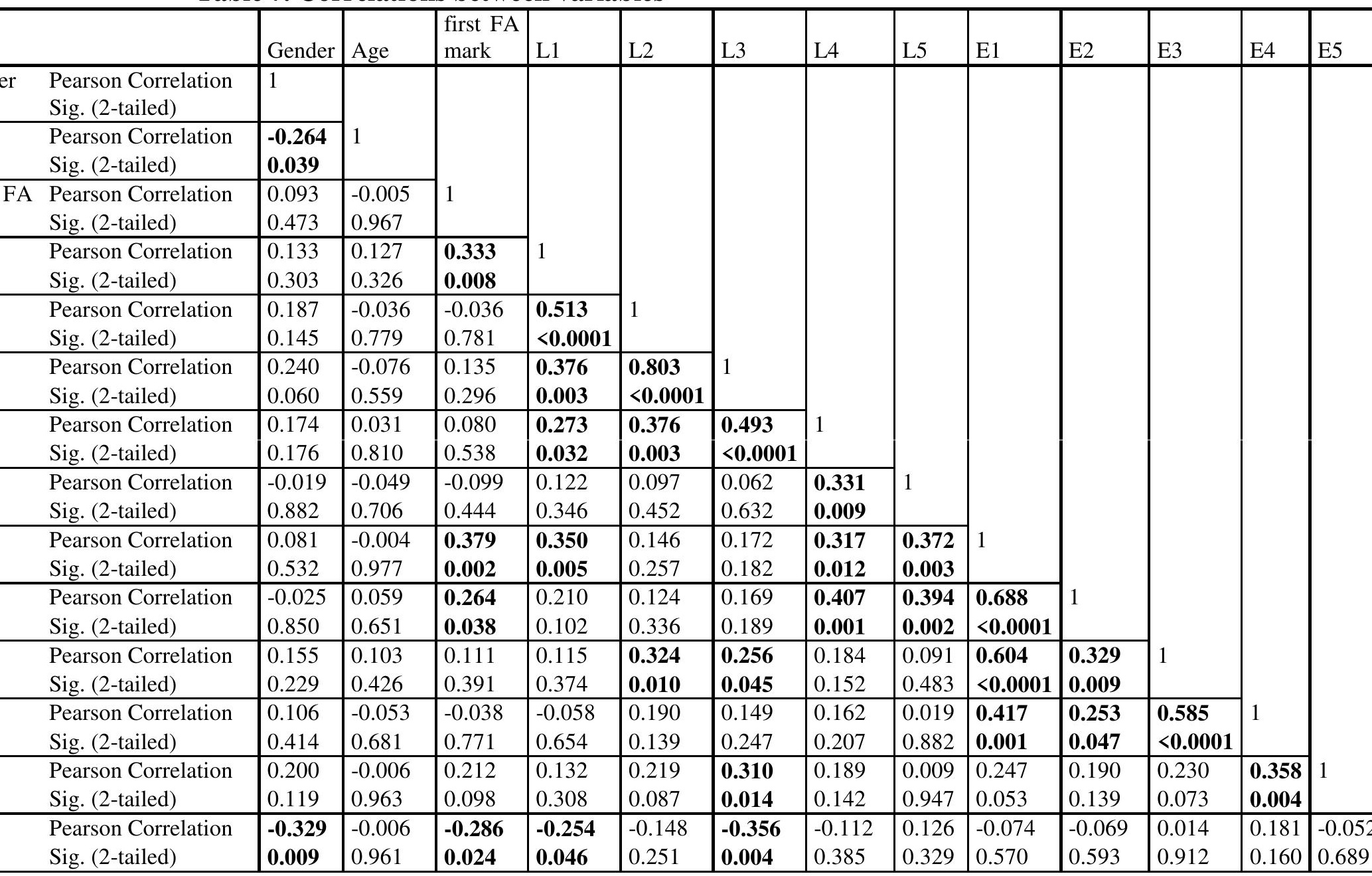

Values in bold are different from 0 with a significance level alpha $=0.05$ 
Table 8. Goodness of fit statistics

\begin{tabular}{|lll|}
\hline Statistic & Independent & Full \\
\hline Observations & 61 & 61 \\
Sum of weights & 61.000 & 61.000 \\
DF & 60 & 27 \\
-2 Log(Likelihood) & 133.186 & 73.485 \\
R²(McFadden $)^{2}$ & 0.000 & 0.448 \\
R$^{2}$ Cox and Snell) & 0.000 & 0.624 \\
R$^{2}$ Nagelkerke) & 0.000 & 0.703 \\
AIC & 137.186 & 141.485 \\
SBC & 141.407 & 213.255 \\
Iterations & 0 & 7 \\
\hline
\end{tabular}


Table 9. Test of the null hypothesis H0: $Y=0.361$

\begin{tabular}{|llll|}
\hline Statistic & DF & Chi-square & Pr $>\mathrm{Chi}^{2}$ \\
\hline -2 Log(Likelihood) & 32 & 59.701 & 0.002 \\
Score & 32 & 39.790 & 0.162 \\
Wald & 32 & 16.316 & 0.990 \\
\hline
\end{tabular}


Table 10. Model parameters

\begin{tabular}{|c|c|c|c|c|c|c|}
\hline Category & Source & Value & $\begin{array}{l}\text { Standard } \\
\text { error }\end{array}$ & $\begin{array}{l}\text { Wald Chi- } \\
\text { Square }\end{array}$ & $\mathrm{Pr}>\mathrm{Chi}^{2}$ & $\begin{array}{l}\text { Odds } \\
\text { ratio }\end{array}$ \\
\hline \multirow{18}{*}{1} & Intercept & -28.115 & 13.730 & 4.193 & 0.041 & \\
\hline & Interest/Enjoyment & -4.018 & 1.806 & 4.949 & 0.026 & 0.018 \\
\hline & Pressure & 2.805 & 1.222 & 5.270 & 0.022 & 16.523 \\
\hline & L1 & 3.621 & 1.656 & 4.783 & 0.029 & 37.375 \\
\hline & L2 & -1.700 & 1.625 & 1.095 & 0.295 & 0.183 \\
\hline & L3 & 0.605 & 1.108 & 0.298 & 0.585 & 1.831 \\
\hline & L4 & 0.241 & 0.769 & 0.098 & 0.754 & 1.272 \\
\hline & L5 & 1.635 & 1.408 & 1.349 & 0.246 & 5.127 \\
\hline & E1 & 2.201 & 1.849 & 1.417 & 0.234 & 9.038 \\
\hline & E2 & 1.885 & 1.061 & 3.156 & 0.076 & 6.585 \\
\hline & E3 & 0.396 & 0.755 & 0.275 & 0.600 & 1.486 \\
\hline & E4 & -0.746 & 0.912 & 0.670 & 0.413 & 0.474 \\
\hline & E5 & 1.670 & 0.823 & 4.117 & 0.042 & 5.311 \\
\hline & E6 & 0.209 & 0.714 & 0.086 & 0.770 & 1.232 \\
\hline & positive & -0.659 & 0.532 & 1.533 & 0.216 & 0.518 \\
\hline & negative & 4.391 & 1.939 & 5.130 & 0.024 & 80.729 \\
\hline & Gender-2 & 0.000 & 0.000 & & & \\
\hline & Gender-1 & -2.515 & 1.440 & 3.053 & 0.081 & 0.081 \\
\hline \multirow{18}{*}{2} & Intercept & -38.658 & 14.330 & 7.277 & 0.007 & \\
\hline & Interest/Enjoyment & -4.995 & 1.891 & 6.977 & 0.008 & 0.007 \\
\hline & Pressure & 4.327 & 1.471 & 8.653 & 0.003 & 75.743 \\
\hline & L1 & 6.082 & 2.059 & 8.726 & 0.003 & 438.013 \\
\hline & L2 & -1.195 & 1.681 & 0.506 & 0.477 & 0.303 \\
\hline & L3 & -1.021 & 1.350 & 0.572 & 0.450 & 0.360 \\
\hline & L4 & -0.114 & 0.786 & 0.021 & 0.884 & 0.892 \\
\hline & L5 & 2.779 & 1.486 & 3.498 & 0.061 & 16.106 \\
\hline & E1 & 5.002 & 2.114 & 5.601 & 0.018 & 148.735 \\
\hline & E2 & 1.058 & 1.135 & 0.870 & 0.351 & 2.881 \\
\hline & E3 & -0.166 & 0.818 & 0.041 & 0.839 & 0.847 \\
\hline & E4 & -1.885 & 1.028 & 3.364 & 0.067 & 0.152 \\
\hline & E5 & 2.914 & 0.936 & 9.700 & 0.002 & 18.429 \\
\hline & E6 & -0.902 & 0.845 & 1.139 & 0.286 & 0.406 \\
\hline & positive & -0.442 & 0.593 & 0.556 & 0.456 & 0.643 \\
\hline & negative & 3.987 & 1.841 & 4.691 & 0.030 & 53.917 \\
\hline & Gender-2 & 0.000 & 0.000 & & & \\
\hline & Gender-1 & -1.944 & 1.461 & 1.771 & 0.183 & 0.143 \\
\hline
\end{tabular}

